\title{
WHISTLEBLOWER LAWS: INTERNATIONAL BEST PRACTICE
}

\author{
PAUL LATIMER* AND A J BROWN**
}

\section{INTRODUCTION}

Since the 1990s, many public law jurisdictions around the world have enacted, or are committed to enacting, legislation to protect public interest whistleblowers. Whistleblower protection legislation has also been passed in the areas of corporate law, workplace relations law, consumer law and financial regulation. This article provides an analysis of this legislation, and identifies several emerging issues for consideration. We identify a strong case for greater consistency in the legal thresholds and operational requirements imposed by whistleblower protection legislation, and make recommendations for common tests and processes covering both the public and private sectors. In large part, the prospect for accelerating the transition towards more effective, less 'symbolic'

* Associate Professor, Department of Business Law and Taxation, Monash University, Melbourne.

** Senior Research Fellow, Law School, Griffith University, Brisbane and Visiting Fellow, Australian National University, Canberra.

1 The research for this article was funded by the Australian Research Council 'Whistling While they Work' (ARC Linkage Project LP0560303) and the industry partners to this project, as listed on the project website <www.griffith.edu.au/whistleblowing $>$ at 18 August 2008. The authors thank their colleagues on the project team as well as the industry partners and the participants for their assistance with this research. For background to this article, see A J Brown, 'Public Interest Disclosure Legislation in Australia: Towards the Next Generation' (Issues Paper, ARC / Griffith University 'Whistling While They Work Project' 2006); A J Brown and Paul Latimer, 'Symbols or Substance? Priorities for the Reform of Australian Public Interest Disclosure Legislation', in Anila V Menon (ed), Whistleblowers: Impact and Implication, ch 9; A J Brown (ed), Whistleblowing in the Australian Public Sector: Enhancing the Theory and Practice of Internal Witness Management in Public Sector Organisations (2008). Senator Andrew Murray of the Australian Democrats tabled the Public Interest Disclosures Bill 2007 (Cth) in the Senate in June 2007, and acknowledged in the Explanatory Memorandum that the Bill 'while not aligned with, is indebted to the authors of the issues paper'. See further Whistleblower Protection - Australian Democrats Action Plan: Whistleblower Protection Accountability (2007)

$<$ http://www.democrats.org.au/docs/ActionPlans/Accountability_Whistleblower_2007.pdf $>$ at 8 September 2008. The project's draft report was released on 24 October 2007: A J Brown, Whistleblowing in the Australian Public Sector, First Report of the Australian Research Council Linkage project; Whistling While They Work: Enhancing the theory and practice of Internal Witness Management in Public Sector Organisations Draft Report (2007) 'Whistling While They Work' Project $<$ http://www.apsacc.com.au/papers07/day1_24oct07/StreamD2/WhistleblowingInAustPublicSector_AJBr own.pdf $>$ at 16 August 2008.

The findings and views expressed in this paper are those of the authors and do not necessarily represent the views of the Australian Research Council or the project industry partners. 
regimes depends on a clearer consensus regarding the public importance of employee disclosures and the organisational advantages of open, proactive approaches to disclosure management.

The track record of whistleblowing has come into focus in recent years. Important Australian research has been carried out by Dr William (Bill) De Maria for almost two decades, who has found 'nothing to celebrate' on his 'tour through the entrails of our society, except for, perhaps, the valour of the whistleblowers who guide us into the netherworld of corruption, incompetence, cover-ups and organisational vendettas'. ${ }^{2}$ There have been anecdotal national overviews which have publicised the issue, but these have only made a limited contribution to improvements in institutional capacity because they presume that capacity to be irreparably low. ${ }^{3}$ The Whistling While They Work Project, which commenced in 2005, is the largest study of its kind ever undertaken in Australia and is one of the largest per capita ever undertaken in the world. It has involved empirical research into whistleblowing in Australian public sector agencies, involving a survey of 7663 public officers from 118 public agencies from the Commonwealth, New South Wales, Queensland and Western Australian Governments.

There are many questions thrown up by the diversity of the current laws. ${ }^{4}$ There are lingering fears that reprisals remain the norm and that legal protection can only ever be symbolic, and that a whistleblower or witness protection scheme is still a poor substitute for effective disclosure laws. Best practice supports disclosure of wrongdoing, and raises the 'hero or traitor' dichotomy. The whistleblower must have trust in the system, and workplace relations support with protection from civil or criminal liability. Best practice includes effective operational systems for the management of whistleblowing. Whistleblower legislation must ensure that whistleblowers are protected from reprisal, retaliation, punishment, retribution and discrimination by employers, organisations and others. Some whistleblower laws protect disclosure of confidential information made in the belief that the disclosure is substantially correct; and some protect disclosure by an informant acting bona fide. Equally, whistleblower laws should not protect disclosure of false information actuated by personal grievance, malice or vindictiveness, and whistleblower best practice

2 William De Maria, Deadly Disclosures: Whistleblowing and the Ethical Meltdown of Australia (1999) xiii; see also William De Maria, 'Queensland Whistleblowing: Sterilising the Lone Crusader' (1992) 27(4) Australian Journal of Social Issues 248; William De Maria, Unshielding the Shadow Culture: Queensland Whistleblower Study, Result Release One (1994); William De Maria and Cyrelle Jan, Wounded Workers: Queensland Whistleblower Study, Result Release Two (1994); William De Maria, 'Whistleblowing' (1995) 20 Alternative Law Journal 270. De Maria's pioneering research was carried out before the modern legislation, involved only one jurisdiction, and relied on a self-selecting sample obtained through public advertisement.

3 Quentin Dempster, Whistleblowers (1997); Brian Martin, Suppression Stories (1997).

4 See, eg, NSW Ombudsman, 'The Adequacy of the Protected Disclosure Act to Achieve its Objectives (Issues Paper, NSW Ombudsman, 2004); Brian Martin, 'Illusions of Whistleblower Protection' (2003) 5 University of Technology, Sydney Law Review 119. 
does punish persons with such inadmissible motives. ${ }^{5}$ It is important for whistleblower laws to promote a culture where honest disclosures are respected, valued, and even rewarded. A failure to support whistleblowers equates to the promotion of the protection of misconduct and wrongdoing.

\section{A Who is a Whistleblower?}

'Whistleblower' or 'whistleblowing' is not a technical term and it does not have a common legal definition. A whistleblower is sometimes described as an 'internal witness', or as a person making 'public interest disclosure', ${ }^{6}$ or 'protected disclosure' 7 or giving 'public interest information'. ${ }^{8}$

Whistleblowing covers disclosure to employers, managers, organisational leaders, regulators and ultimately disclosures to the public (including disclosures to the public via the media). It excludes the airing of complaints and personal grievances, even though these may have a public interest dimension, where such grievances are not able to be resolved. In the words of Calland and Dehn, '[w]histleblowing is now used to describe the options available to an employee to raise concerns about workplace wrongdoing'. ${ }^{9}$ The test is not the whistleblower's subjective motives or ethics (complaints or grievances) but the whistleblower's perception or reason to believe that there has been wrongdoing. This article uses the definition of Near and Miceli ${ }^{10}$ that whistleblowing involves 'the disclosure by organisation members (former or current) of illegal, immoral, or illegitimate practices under the control of their employers, to persons or organisations that may be able to effect action'. This broad definition is in line with most public understandings of what a whistleblower is, why their actions are important, and why they are often likely to require protection.

\section{B Whistleblowers as Heroes and Traitors}

Whistleblowing raises the tension between the whistleblower as hero or as traitor. Are whistleblowers heroes who expose illegal and corrupt conduct, maladministration, misconduct and wastage, or are they traitors because they

\footnotetext{
See, eg, Public Interest Disclosures Bill 2007 (Cth) cl 31.

See, eg, Public Interest Disclosure Act 1994 (ACT) s 3; Whistleblowers Protection Act 1994 (Qld) sch 6.

7 See, eg, Public Servants Disclosure Protection Act, SC 2005, c 46, s 2; Protected Disclosures Act 1994

(NSW) s 2, pt 2; Protected Disclosures Act 2000 (NZ) s 6(2).

$8 \quad$ See, eg, Public Interest Disclosure Bill 2007 (Cth) cl 5.

9 Richard Calland and Guy Dehn, 'Introduction - Whistleblowing Around the World: the State of the Art', in Richard Calland and Guy Dehn (eds) Whistleblowing Around the World: Law, Culture \& Practice (2004) 9; see also, Bjorn Rohde-Liebenau, Whistleblowing Rules: Best Practice; Assessment and Revision of Rules Existing in EU Institutions (2006) European Parliament, 16

$<\mathrm{http}: / /$ www.europarl.europa.eu/comparl/cont/site/calendrier/documents/3mai06/etude.pdf $>$ at 18 August 2008.

10 Janet Near and Marcia Miceli, 'Organisational Dissidence: the Case of Whistleblowing' (1985) 4 Journal of Business Ethics 1, 4; adopted by, eg, Brown, Whistleblowing in the Australian Public Sector, above n 1, 3; Marcia Miceli and Janet Near, Blowing the Whistle: the Organisational and Legal Implications for Companies and Employees (1992).
} 
disclose confidential information and practices? ${ }^{11}$ If seen as traitors, whistleblowers may become the victim of reprisals and retaliation, harassment and poor management. If seen as heroes, they may promote high standards in public life and public bodies. ${ }^{12}$ An informed society underpins a democratic society, and a democratic society must encourage, support and protect whistleblowers. Courts around the world have tried to reconcile an employee's duty of loyalty to his or her employer with the public interest in the disclosure and suppression of unlawful activity. ${ }^{13}$

\section{Pre-requisites for Whistleblower Laws}

Whistleblower laws can only work in a democratic society which supports transparency, disclosure and accountability. A whistleblower who wishes to disclose bribery, corruption and patronage networks may live in a dictatorship with no rule of law, governed by secrecy, fear, reprisal and death. ${ }^{14}$ Whistleblower laws must be seen in the context of culture. They cannot be exported to hostile environments. ${ }^{15}$ A precondition for whistleblower laws is the rule of law, including an independent legal system and an independent judiciary.

Transparency International is a non-government global coalition against corruption based in Berlin which collects and disseminates data and information on governance and corruption trends around the world. It found in a recent report that there are no, or at least no comprehensive, whistleblower laws in countries including Argentina, Germany, Ghana, Guatemala, Indonesia, Italy, Kenya, Panama, Philippines, Ukraine and Venezuela. The report does not mention countries such as Brazil, Mexico, Namibia, Nigeria, Portugal, Russia, Turkey and Zimbabwe. ${ }^{16}$ This correlates with Transparency International's Corruption

11 See, eg, Rohde-Liebenau, above n 9, 14; Michael Walsh, In-focus: Whistleblowing: Betrayal or Public Duty? (2005) Edmund Rice Business Ethics Initiative

$<\mathrm{http}: / /$ www.erc.org.au/goodbusiness/page.php?pg=0506infocus122> at 18 August 2008; Paul Latimer, 'Heroes or Traitors?' (2006) 2(1) Monash Business Review 34.

12 See, eg, National Commission to Review the Working of the Constitution, Probity in Governance (2001) [3.4.9] <http://lawmin.nic.in/ncrwc/finalreport/v2b1-12.htm> at 13 August 2008, where in referring to Standards in Public Life, it is cited that in the UK, the recommendations of the Nolan Committee in 1996 were accepted by the Major Government in its 1997 White Paper: Great Britain Cabinet Office, The Governance of Public Bodies (Command Paper) (1997).

13 See, eg, the Supreme Court of Canada in Merk v International Association of Bridge, Structural, Ornamental and Reinforcing Iron Workers, Local 771 [2005] 3 SCR 425, [26], citing European, New Zealand and UK authorities, which included the so-called Whistleblowers' Charter 1999 in the European Union, administered by the Anti-Fraud Office of the European Commission, which provides that employees must first exercise all internal avenues for reporting misconduct before they can blow the whistle.

14 Estanislao Oziewicz, 'Polonium is Costly, Undetectable, Trillion Times More Toxic than Cyanide', globeandmail.com, 2 December $2006<$ www.theglobeandmail.com> at 8 September 2008.

15 William de Maria, 'Whistleblower Protection: is Africa Ready?' (2005) 25(3) Public Administration and Development 217, 224: 'In countries experiencing human rights violations the more suitable strategies may well be secret reporting, armed struggle, street protests and subversive action'.

16 Transparency International: the Global Coalition against Corruption, Transparency International's National Integrity System Approach $<\mathrm{http} / / / \mathrm{www}$.transparency.org/policy_research/nis $>$ at 16 August 2008. 
Perceptions Index for 2006, which scored Finland, Denmark and New Zealand as the world's least corrupt countries, and placed Iraq, Myanmar and Somalia at the opposite end of the spectrum. ${ }^{17}$

\section{PUBLIC SECTOR WHISTLEBLOWER PROTECTION LAWS}

Many jurisdictions have passed legislation to protect public sector and sometimes private sector employees who make public interest disclosures. These include Australia, ${ }^{18}$ Canada, ${ }^{19}$ France, ${ }^{20}$ India, ${ }^{21}$ Japan, ${ }^{22}$ New Zealand, ${ }^{23}$ South Africa, ${ }^{24}$ the United Kingdom, ${ }^{25}$ and the United States. ${ }^{26}$

17 Inken Denker (ed), Corruption Perceptions Index 2007 (2007) Transparency International: the Global Coalition against Corruption $<$ http://www.transparency.org/policy_research/surveys_indices/cpi/2007>at 16 August 2008.

18 For example, in Australia, there are at least 11 Acts or Bills on public interest disclosures: Public Service Act 1999 (Cth) s 16; Public Interest Disclosures Bill 2007 (Cth); Public Interest Disclosure Act 1994 (ACT); Public Interest Disclosure Bill 2006 (ACT); Protected Disclosures Act 1994 (NSW); Public Interest Disclosure Bill 2005 (NT); Whistleblowers Protection Act 1994 (Qld); Whistleblowers Protection Act 1993 (SA); Public Interest Disclosures Act 2002 (Tas); Whistleblowers Protection Act 2001 (Vic); Public Interest Disclosure Act 2003 (WA). Irene Moss, Report of the Independent Audit into the State of Free Speech in Australia (2007)

$<$ http://www.abc.net.au/news/opinion/documents/files/20071105_righttoknow.pdf $>$ at 17 August 2008 ('Moss Report'), made a 'strong case' in Chapter 5 for uniform public interest disclosure legislation. The Rudd Government has stated that it will 'implement public interest disclosure reform for whistleblowers': Australian Labor Party, Government Information - Restoring Trust and Integrity (2007)

$<$ http://www.alp.org.au/download/now/071026_government_information_policy.pdf $>$ at 17 August 2008.

19 See eg, Public Servants Disclosure Protection Act, SCC 2005, c 46; Final Report of the Former Public Service Integrity Office of 2005/2006 (2006) <http://www.psio-bifp.gc.ca/media/communique/2004-1117 e.php $>$ at 17 August 2008. The Canadian Charter of Rights and Freedoms, Part 1 of the Constitution Act, 1982, being Schedule B to the Canada Act 1982 (UK) 1982, may protect public servant freedom of expression about their employers. There are whistleblower laws in several Canadian provinces such as New Brunswick, Manitoba and Ontario. The Employment Standards Act, SNB 1982, c E-7.2, s 28 provides the most general whistleblower protection amongst the Canadian provinces: Keith Archer, From Rhetoric to Reality: Protecting Whistleblowers in Alberta (2005) The Parkland Institute

$<$ http://www.ualberta.ca/PARKLAND/research/studies/Whistleblower\%20report.pdf $>$ at 17 August 2008.

20 The Auroux Law passed in France on 23 December 1982 recognises an employee's droit d'alerte et de retrait (right to notify and to withdraw). French law protects the whistleblower (lanceur d'alerte, donneur d'alerte; in Quebec, fonctionnaires divulgateurs d'actes répréhensibles, dénonciateur).

21 Public Interest Disclosure (Protection of Informers) Bill 2002. The Indian Bill is discussed on the weblog Two Democracies: USA and India (2006) <http://2democracies.blogspot.com/2006/09/notes-for-indiasproposed.html> at 17 August 2008.

22 Whistleblower Protection Act 2004 (Japan); See, eg, Leon Wolf, 'New Whistleblower Protection Laws for Japan' (2004) 17 Journal of Japanese Law 209.

23 Protected Disclosures Act 2000 (NZ).

24 Protected Disclosures Act 2000 (South Africa); see, eg, Jeannette Campbell, Dare I Blow the Whistle? Is Adequate Protection Given to SA Employees in Terms of the Protected Disclosures Act 26 of 2000 ? (Research Report, University of Wollongong, 2004)

$<$ http://www.uow.edu.au/arts/sts/bmartin/dissent/documents/Campbell.pdf $>$ at 17 August 2008.

25 Public Interest Disclosure Act 1998 (UK), adding Pt IVA ss 43A-43L (Protected Disclosures) to Employment Rights Act 1996 (UK), in force in July 1999. This is internationally recognised as a benchmark for public interest whistleblowing; see, eg, Public Concern at Work $<$ http://www.pcaw.co.uk> at 17 August 2008. 
Often the legislation has a long title, ${ }^{27}$ for instance '[a]n Act to establish a procedure for the disclosure of wrongdoings in the public sector, including the protection of persons who disclose the wrongdoings' (Canada), or 'to promote compliance with the laws and regulations concerning the protection of life, body, property, and other interests of citizen, and thereby to contribute to the stabilisation of the general welfare of the life of the citizens and to the sound development of socio-economy' (Japan) or '[a]n Act to provide protection for public officials disclosing corrupt conduct, maladministration and waste in the public sector; and for related purposes' (New South Wales).

In addition to these specific whistleblower provisions, there are many other protected disclosures in public and private sector legislation regarding, for example, anti-corruption legislation, ${ }^{28}$ auditors, ${ }^{29}$ competition law, ${ }^{30}$ corporations law, ${ }^{31}$ occupational health and safety ${ }^{32}$ and workplace relations and employment law. ${ }^{33}$ There is mandatory reporting in many areas of public concern including

26 Whistleblower Protection Act 5 USC (1989). The Sarbanes-Oxley Act 18 USC (2002) amended Chapter 73 of title 18, United States Code, by inserting important new whistleblower provisions in s 1514A to provide '[c]ivil action to protect against retaliation in fraud cases'.

27 The long title sets out the purpose of the legislation, and may be referred to as an aid in the interpretation of the legislation, so long as it does not contradict any clear and unambiguous language in the legislation.

28 See, eg, Anti-Corruption Act 2003 (Namibia) s 17 (Notification to Commission of corrupt practice); Corrupt Practices and other Related Offences Act 2000 (Nigeria) s 23 (Duty to report bribery transactions)

29 See, eg, Pensions Act 1995 (UK) c 26, s 48, headed 'Blowing the whistle', which authorises an auditor or actuary of any occupational pension scheme who has cause to believe that there has been a breach of duty by specified persons or other failure to comply to give a written report to the Occupational Pensions Regulatory Authority. In the Singapore Code of Corporate Governance (2005), the Audit Committee must ensure that the company has provisions in place for employees to raise any concerns in confidence regarding any act of misfeasance by management, with follow-up and independent investigation of the concerns.

30 See, eg, Competition Act, RSC 1985, c C-34, s 66.1, headed 'Whistleblowing', which authorises any person who has reasonable grounds to believe that a person has committed or intends to commit an offence under the Act, to notify the Commissioner, and may request that his or her identity be kept confidential.

31 See, eg, Corporations Act 2001 (Cth) pt 9.4AAA, which was introduced into the Corporations Act 2001 (Cth) by the Corporate Law Economic Reform Program (Audit Reform and Corporate Disclosure) Act 2004 (Cth). The Corporations Act 2001 (Cth) now protects disclosures by an officer or an employee of and supplier and employee of supplier to a 'company' to ASIC, the company's auditor, a director or other management, or an authorised person (s 1317AA); South Korea: Securities and Exchange Act 2003 as amended by Law 7025 of 31 December 2003. See, eg, Paul Latimer, 'Whistleblowing in the Financial Services Sector' (2002) 21 University of Tasmania Law Review 39; Paul Latimer, 'Reporting Suspicions of Money Laundering and "Whistleblowing": the Legal and other Implications for Intermediaries and their Advisers' (2002) 10 Journal of Financial Crime 23; Paul Latimer, 'Whistleblowing in the insurance industry' (2003) 77 Australian Law Journal 614; Paul Latimer, 'Whistleblowing in the Financial Services Sector (Part 2)' (2004) 23 University of Tasmania Law Review 176.

32 See, eg, Margaret Banks, Asbestos Alert (2008) Stop. Think Asbestos. Seek Advice - Northern Territory of Australia $<$ http://www.asbestos.nt.gov.au> at 18 August 2008.

33 Workplace Relations Act 1996 (Cth) pt 4A was added to sch 1, Chapter 11 in 2004, two weeks after the Corporations Act amendments, by the Workplace Relations Amendment (Codifying Contempt Offences) Act 2004 (Cth) sch 1A, in force 13 July 2004. 
anti-terror legislation ${ }^{34}$ and child abuse. ${ }^{35}$ There are whistleblower provisions in the common law such as those regarding accountants ${ }^{36}$ and bankers. ${ }^{37}$ The Sarbanes-Oxley Act USC (2002) ('SOX'), passed in the US to restore public confidence in corporate America after major corporate and accounting scandals, includes section 806 to protect employees of publicly traded companies who provide evidence of fraud. ${ }^{38}$ SOX areas include auditor independence; corporate responsibility; enhanced financial disclosures; analyst conflicts of interest; Commission resources and authority; Commission studies and reports; corporate and criminal fraud accountability; white-collar crime penalty enhancements; corporate tax returns; corporate fraud and accountability.

The result of this diversity of provisions is that an employee of an organisation operating globally may be permitted to blow the whistle for mismanagement in one jurisdiction, but not for the same mismanagement occurring in the same organisation but in another jurisdiction. This is not sensible in the global economy.

\section{A Whose disclosures are protected?}

Many international whistleblower laws fall far short of the ideal, and there is a large variation amongst various threshold tests of who can make a protected disclosure. Some protected disclosures are limited to disclosures by employees only. ${ }^{39}$ Others extend protection of disclosure by an employee to related classes such as full time, part-time, permanent and temporary staff, as well as to external consultants, contractors and secondees. In order to avoid 'loopholes' in whistleblower legislation, protection should also extend to applicants for employment, contracts and funding (especially important in the case of

34 See, eg, the Financial Transaction Reports Act 1988 (Cth) and the Anti-Money Laundering and CounterTerrorism Financing Act 2006 (Cth) which establish mandatory reporting by financial services providers (such as banks, bullion dealers and solicitors) and the gambling industry. This mandatory reporting involves verification of customer identification.

35 See, eg, Daryl Higgins, Leah Bromfield and Nick Richardson, 'Mandatory Reporting of Child Abuse', Australian Institute of Family Studies, Resource Sheet Number 3, August 2007.

36 Janet Baker Jones, 'Whistleblowing - No Longer Out of Tune' (1996) 66(7) Australian Accountant 56.

37 See, eg, Tournier v National Provincial and Union Bank of England [1924] 1 KB 461; John Walter and Nathan Erlich, 'Confidences - Bankers and Customers: Powers of Banks to Maintain Secrecy and Confidentiality’ (1989) 63(6) Australian Law Journal 404.

38 Section 806 adds s 1514 A to Chapter 73 of title 18 of the US Code. Section 1514A(a) is headed '(a) Whistleblower protection for employees of publicly traded companies'; see, eg, Beverley Earle and Gerald Madek, 'The Mirage of Whistleblower Protection Under Sarbanes-Oxley: A Proposal for Change' (2007) 44(1) American Business Law Journal 1.

39 See, eg, under Employment Rights Act 1996 (UK) pt IVA, see David Lewis and Stephen Homewood, Five years of the Public Interest Disclosure Act in the UK: are Whistleblowers Adequately Protected? (2004) Web Journal of Current Legal Issues, 5 <http://webjcli.ncl.ac.uk/2004/issue5/dlewis5.html\#Heading96> at 18 August 2008. 
blacklisting). ${ }^{40}$ It should also include those who are formerly employed, unemployed or otherwise blacklisted.

\section{$1 \quad$ Public Sector Employees}

Some whistleblower laws are limited to providing whistleblower protection to disclosures in the public sector ${ }^{41}$ and often contain loopholes, ${ }^{42}$ while others provide private sector protection. Still others take a hybrid approach and provide public sector disclosure protection of matters in the private sector. Public sector whistleblowers are important to maintain transparency in government, but difficulties always arise in relation to the scope of whistleblowing by law enforcement and intelligence agencies.

\section{Whistleblowing by Contractors}

Public sector functions may be outsourced to a 'contractor', a person not under public service conditions and controls, who carries out government functions. This contractor is the equivalent of a government official - many third parties would not know the difference - and should be the subject of protected disclosures. ${ }^{43}$ Best practice, as exemplified by the UK, is to extend employment law by giving the contactor whistleblower protection. ${ }^{44}$ Under section 230(3) of

40 Tom Devine, International Best Practices for Whistleblower Policies at Intergovernmental Organizations (2007) Government Accountability Project [5]

$<$ http://www.whistleblower.org/doc/IGO\%20Best\%20Practices\%20checklist1.doc > at 18 August 2008 , citing, eg, United Nations Secretariat, Protection against Retaliation for Reporting Misconduct and for Cooperating with Duly Authorised Audits or Investigations (2005) United Nations s 8

$<$ http://www.un.org/depts/oios/wb_policy.pdf> at 18 August 2008, which protects whistleblowing by 'a contractor or its employees, agents or representatives or any other individual engaged in any dealings with the United Nations' ('UN Policy'); Organisation of American States, Model Law, Protecting Freedom of Expression Against Corruption Government Accountability Project s 2(b)

$<$ http://www.whistleblower.org/content/press_detail.cfm?press_id=51> at 18 August 2008, providing that “"person”... means "any party”" ('OAS Model Law').

41 See, eg, the Whistleblower Protection Act 5 USC (1989) which protects whistleblowing employees of federal government corporations - 'patriotic truth-tellers' - from reprisal and provides for redress. The Public Servants Disclosure Protection Act, SCC 2005, c 46 also applies only to disclosure by members of the Canadian federal public service including the RCMP (Mounties), and to a number of federal Crown corporations. Equally, most of Australia's nine whistleblower Acts provide whistleblower protections in only the public sector: see, eg, Protected Disclosures Act 1994 (NSW) s 8 (Disclosures must be made by public officials); Whistleblowers Protection Act 1994 (Qld) ss 8, 15-18. Some jurisdictions provide a hybrid scheme, such as protection for a public officer who discloses conduct in the public or private sectors (eg Whistleblowers Protection Act 1994 (Qld) s 18). Some provide for certain disclosures by 'anybody' (eg Whistleblowers Protection Act 1994 (Q1d) ss 19, 20 'Anybody may disclose...') or target any conduct (eg Independent Commission Against Corruption Act 1988 (NSW) s 8(1), which defines 'corrupt conduct' as 'any conduct...'

42 The US Act is not a 'no loopholes' statute as there is no whistleblower protection for whistleblowers in agencies like the CIA, FBI, Defence Intelligence Agency, Justice Department, Transportation Security Administration, and the National Security Agency: Homeland and National Security Whistleblower Protections: the Unfinished Agenda (2005) Project on Government Oversight $<$ http://www.pogo.org/p/government/go-050402-whistleblower.html> at 18 August 2008

43 See, eg, Public Interest Disclosure Bill 2006 (ACT) s 10(1)(a)(ii).

44 Employment Rights Act 1996 (UK) c 18, s 43K. 
the Employment Rights Act 1996 (UK), a worker includes an employee and an independent contractor who himself provides services other than in a professional/client or a business/client relationship. In contrast, the South African Act excludes the independent contractor from whistleblower protection. ${ }^{45}$

Another type of contractor is the third person who contracts with government and government agencies. This contractor may have evidence of being asked for kickbacks, bribes and sweeteners in order to be awarded a potentially lucrative government contract. It is therefore important to maintain integrity in the contracting process by ensuring that whistleblower laws especially encourage contractors to disclose corrupt conduct.

\section{Anonymous Disclosures}

The heroes or traitors dichotomy crystallises with the question of anonymity. On the assumption that anonymity may make the whistleblower unaccountable, and may attract cranks, timewasters and the querulents, many jurisdictions exclude anonymous whistleblower disclosures and provide that they will not be acted upon ${ }^{46}$ Only rarely does legislation accept and protect anonymous disclosures, ${ }^{47}$ as it is certainly better than not disclosing at all. However, as a matter of policy, anonymous whistleblowing should be seen as a last resort.

Requiring whistleblower identification may introduce some accountability, but it may also discourage disclosure. Best practice aims to maximise the flow of information necessary for accountability and to provide reliable protected channels for anonymous disclosures. ${ }^{48}$

Whistleblower legislation diverges from disclosure in other areas, such as the obligation of auditors to disclose evidence of corporate fraud, corruption or theft. The Australian Competition and Consumer Commission ('ACCC') adopts a policy of 'full amnesty' (immunity from prosecution) for the first person who blows the whistle on cartel activity such as price fixing and market sharing. ${ }^{49}$

\section{$4 \quad$ Future Directions - the Link for Whistleblower Protection}

The instant focus on public sector whistleblowers results from the origin of so many whistleblower laws in that sector. Few legislative instruments allow for disclosure by 'anybody' or members of the public. The international standard is to limit whistleblowing to disclosure by employees - public and/or private sector

45 Protected Disclosures Act 2000 (South Africa) s 1(ii)(a).

46 See, eg, Public Interest Disclosure Act 1994 (ACT) s 16; under the Public Interest Disclosures Act 2002 (Tas) s 34(2), anonymous reports are not reported to the Ombudsman.

47 See, eg, Public Interest Disclosures Bill 2007 (Cth) cl 10; Whistleblowers Protection Act 1994 (Qld) s 27(1); Public Interest Disclosures Act 2002 (Tas) s 8; Whistleblowers Protection Act 2001 (Vic) s 7; Rohde-Liebenau, above n 9, 34

48 Devine, above n 40, [6], citing, eg, UN Policy, above n 40, s 5.2; OAS Model Law, above n 40 arts 10(5), $20-2$.

49 Immunity Policy for Cartel Conduct (2005) Australian Competition \& Consumer Commission cl 11(a)(iii) $<$ http://www.acc.gov.au/content/item.phtml?itemId=708758\&nodeId=b42265c $7 \mathrm{fbeee} 88 \mathrm{cf} 1 \mathrm{~cd} 2851 \mathrm{c} 337 \mathrm{c}$ 446\&fn=Immunity\%20policy.pdf $>$ at 18 August 2008 . 
- and related classes. ${ }^{50}$ We suggest that in time there may be a case for whistleblowing laws to move to a full 'no loopholes' approach, targeting public sector and private sector whistleblowing with sector-blind principles and practices. There is a role for members as whistleblowers, such as whistleblowers in churches and religious organisations, national and international nongovernment organisations ('NGOs'), political parties and trade unions - and indeed members of the public - as they may be in the best position to see that services are not being delivered owing to wrongdoing.

Members of the public may feel confident about reporting as they are not employees, but they and/or their family and connections may still suffer reprisals if identified. In time the best practice model would provide across the board protection of disclosure by 'anybody' or 'any person', 51 whether public sector or private sector. Some jurisdictions do permit disclosure by 'anyone'. The Northern Territory Law Reform Committee has recommended disclosure by any 'person', as occurs in the South Australian legislation. ${ }^{52}$

We argue that institutional or employment connection is crucial to whistleblower legislation. First, their internal position means that whistleblowers will have information which is worthy of disclosure. Other complainants who are members of the public rarely have the same access to information and insights. Secondly and perhaps most importantly, whistleblowers' internal position renders them vulnerable and they thus require special legal and management protection as well as encouragement to come forward. Members of the public do not usually need legislative protection to report wrongdoing, especially concerning services or matters that affect them personally, because they are not normally subject to the same organisational loyalties and risks of reprisal that affect an organisation's own employees. Thirdly, there is no reason for whistleblower laws to remain focused on 'any person'. In most jurisdictions, the consequences of unlimited whistleblowing are more negative than positive, diluting the purpose and focus of the legislation, confusing its operation and creating 'floodgate' fears about the potential number of complaints, which have in turn led to attempts to narrow the scope or implementation of the legislation in other areas (such as by limiting the types of wrongdoing that may be reported).

Without the internal witness prerequisite, the reputation of the legislation may suffer because it may be used by complainants who are not actually whistleblowers as an alternative avenue for pursuing non-whistleblowing grievances. Such complainants may feel frustrated and end up unhappy, because

50 See, eg, Whistleblower Protection Act 2004 (Japan) art 2, which is limited to reporting by a whistleblowing 'worker'; the Employment Rights Act 1996 (UK) c 18 promotes public and private sector disclosure, but protected disclosure is limited to a 'worker' under the Act.

51 See, eg, Public Interest Disclosure Act 1994 (ACT) s 15(1) ('[a]ny person may make a public interest disclosure'); Public Interest Disclosure Bill 2005 (NT) s 7(1) ('[a] natural person who believes....').

52 Northern Territory Law Reform Committee, Report on Whistleblowers Legislation Report No 26 (2002) Northern Territory Government $2<$ http://www.nt.gov.au/justice/docs/lawmake/whistleblowers.pdf $>$ at 18 August 2008; Whistleblowers Protection Act 1993 (SA) s 4. 
the legislation was not designed to help them, but the open standing provision created a strong legal illusion that it could.

We recommend that:

- Those jurisdictions which currently provide open standing for the making of disclosures about public sector matters should return to the original goal of whistleblower protection by providing that it is only public officials - and others who might properly be classified as 'internal' to the public sector - whose disclosures may trigger the Act; and

- All jurisdictions should provide other complainants with general protection against reprisals in other legislation if it does not already exist, such as through standard anti-reprisal provisions in criminal law or the enabling legislation of investigative agencies such as the ombudsman or health care complaints commissioners. These provisions would mirror existing offences, such as perversion of the course of justice and witness intimidation.

\section{B Disclosure Channels - Disclose to Whom}

Whistleblower legislation provides for protected disclosure to 'appropriate' or 'proper' authorities or public officials such as the Auditor-General, the Ombudsman, the anti-corruption authority, members of parliament and/or the police. Best practice provides for a person or agency - independent of the employer or government - to whom a whistleblower can disclose. In some jurisdictions, disclosure can be made to private persons, for instance those in the media. There should be proper procedures, confidentiality, and protection against exposure and reprisals, such as attempts to discredit the discloser. A common external reporting agency may be logical, but this may be beset with difficulties because whistleblowing obligations are sourced in so many different statutes at different levels of government.

This best practice would have been drafted with local interests in mind, but in a global world it results in the illogic of a whistleblower in a company operating in one jurisdiction being able to disclose misconduct occurring in that jurisdiction, but the equivalent whistleblower in the same company operating in another jurisdiction not being able to disclose the same misconduct in that other jurisdiction.

\section{Internal Disclosure to the Employer}

Recognising that public sector whistleblowing is initially an internal employer/employee matter, the best practice model promotes, protects and respects internal disclosure and resolution by disclosure in the first instance to the whistleblower's supervisor or manager (rather than a colleague) orally or in writing. Hence, there should be whistleblower disclosure procedures in place 
within organisations. ${ }^{53}$ If the concerns of the whistleblower remain unresolved, best practice should promote and protect the whistleblower by providing disclosure to those higher up in the organisation's chain of command. If a whistleblower is uncomfortable with this, the whistleblower should be encouraged to disclose higher up in the organisation to employer representatives such as to the Human Resources officer; the corporate complaints unit; a health and safety representative; a union official; an employee representative; the employer organisation's executive level or its parent company, lawyers or external auditors; or to a commercial reporting hotline.

\section{External Disclosure to Authority}

Only if internal disclosure fails should there be disclosure to external agencies, entities or regulators. There are many reasons for which a whistleblower may prefer to disclose wrongdoing to an external authority. A whistleblower may not have confidence that the matter will be dealt with in an appropriate manner, or may not have time to disclose internally, especially if there is a serious offence or if there is an imminent risk of danger to life, health or safety or to the environment. Some may fear reprisal at work such as attempts to discredit or ridicule them or demotion.

\section{(a) External Integrity Agencies ${ }^{54}$}

Best practice provides for the existence and the identification of independent central and integrity agencies for a whistleblower to report to such as:

- $\quad$ proper authorities', ${ }^{55}$ administrative agency or administrative organ, ${ }^{56}$ a public interest disclosure agency, ${ }^{57}$ public employment agencies or a 'prescribed person'; 58

53 See, eg, in Australia, the Public Service Act 1999 (Cth) s 16 and Public Service Regulations 1999 (Cth) reg 2.4(1) which require agency heads to establish procedures, which are to include procedural fairness, for dealing with whistleblower reports, and to provide that Australian Public Service ('APS') employees in the agency may report breaches or alleged breaches of the APS Code of Conduct to the agency head, the Public Service Commissioner or the Merit Protection Commissioner. Section 16 of the Public Service Act 1999 (Cth) prohibits victimisation of, or discrimination against, a public servant whistleblower. In New Zealand, every public sector organisation must 'have in operation appropriate internal procedures for receiving and dealing with information about serious wrongdoing in or by that organisation': Protected Disclosures Act 2000 (NZ) s 11(1). In the UK, the Civil Service Code (June 2006), [15]-[18], provides for internal and then external disclosure to the Civil Services Commissioners, $<$ http://www.civilservice.gov.uk/iam/codes/cscode/code3.asp > at 18 August 2008.

54 Government of Canada Public Service Integrity Office, A Comparative International Analysis of Regimes for the Disclosure of Wrongdoing ('Whistleblowing') (2004) <http://dsppsd.pwgsc.gc.ca/Collection/CP54-5-2004E.pdf> at 18 August 2008.

55 Public Interest Disclosure Bill 2007 (Cth) cl 8. 
- $\quad$ the Auditor-General; ${ }^{59}$

- the Counsel; 60

- corruption bodies;

- Ombudsmen; 61

- $\quad$ the police 62 and the Director of Public Prosecutions (DPP);

- $\quad$ Public Protector (South Africa);

- $\quad$ relevant policy agencies; and

- $\quad$ trade unions. ${ }^{63}$

Some jurisdictions provide for appeals to higher authorities like the Ombudsman. ${ }^{64}$ With so many agencies involved, it is important that their roles be coordinated, and that they fulfil those responsibilities that can only be properly fulfilled by agencies with independence from frontline agencies.

56 See, eg, the definition in the Whistleblower Protection Act 2004 (Japan) art 2(4): (i) The Cabinet Office, Imperial Household Agency, any organs specified in the Cabinet Office law, organs specified in the National Government Organisation Law, organs under the jurisdiction of the Cabinet, organs established under such organ, or personnel of the above, and organs of local public entities (paraphrased). In the US, designated agencies include the Department of Labour/Office of Administrative Law Judge, and in the case of $S O X$ whistleblowing, the Occupational Safety and Health Administration. There is a recommendation that $S O X$ whistleblowing should be moved to the SEC as SOX whistleblowers disclose breaches of securities laws and accounting practices: Earle and Madek, above n 38, 52.

57 Such as specialist agencies like the Police Integrity Commission ('PIC').

58 See, eg, Public Interest Disclosure Act 1998 (UK) c 23, s 43F - a qualifying disclosure may be made to persons prescribed by the Secretary of State. The following are examples of some of the key regulators prescribed under the Act:

1. Health \& Safety risks: HSE and relevant local authority

2. Utilities/Sectors: Rail Regulator, Charity Commission

3. Financial Services: Financial Services Authority, HM Treasury (insurance), Occupational Pensions Regulatory Authority, Serious Fraud Office

4. Tax irregularities: Inland Revenue, Customs \& Excise

5. Public finance: National Audit Office, Audit Commission, Audit Scotland

6. Company law: Department of Trade and Industry

7. Competition \& consumer issues: Office of Fair Trading and relevant local authority

59 See, eg, New Zealand, South Africa.

60 Public Service Act, RSO 1990, c P.47, s 28.14 (Part IV Whistleblowers' Protections).

61 See, eg, Protected Disclosures Act 2000 (NZ) s 10(1); European Ombudsman $<$ http://www.ombudsman.europa.eu/home/en/default.htm> at 18 August 2008; Ombudsman Act 1995 (Malta) s 13: 'a Commissioner for Administrative Investigations' - to investigate administrative functions of government, statutory bodies and local councils by any person aggrieved.

62 See, eg, disclosure to the police as an 'appropriate authority': Whistleblowers Protection Act 1993 (SA) s 5(4)(a).

63 Lewis and Homewood, above n 39, pt 5.

64 See, eg, Canada, where there is appeal to the Public Servants' Disclosure Protection Tribunal, made up of distinguished lawyers, set up under the Public Servants Disclosure Protection Act, SC 2005, c 46 ('Canadian Act'). 


\section{(b) Disclosure to a 'One Stop Shop'}

One model to consider for external reporting would be the creation of a new central agency such as a Public Interest Disclosure Agency to provide a 'one stop shop' approach to whistleblowing by receiving, investigating and managing all whistleblower matters, including reprisal and dismissal. One difficulty with this is that it may involve duplicating the arrangements already in place by the external integrity agencies mentioned above, and it would require coordination and cooperative efforts with them. This is likely to be beyond the will of most jurisdictions, especially state and provincial jurisdictions in a federation like Australia or the United States.

One example of a new central agency at the federal level is Canada's Office of the Public Sector Integrity Commissioner ('Commissioner'), set up to receive reports from public servants of wrongdoing, to investigate them and to make recommendations to correct them. ${ }^{65}$ The confidentiality of the whistleblower and the persons alleged to be responsible for the wrongdoing are protected if the disclosures are made under the Act. The Canadian Act demonstrates the importance of follow-through by providing that when the Commissioner makes a report to a chief executive, it may request that the executive provide notice of any actions taken to implement the Commissioner's recommendations, or the reasons as to why no action was taken. ${ }^{66}$ The Commissioner may report the matter to the responsible Minister if a matter constitutes an imminent risk of danger to the life, health or safety of persons or the environment. ${ }^{67}$ The Commissioner's powers are, however, limited to making recommendations, which may not be reviewable by a court.

Similarly, the UK's Office of the Civil Service Commissioners, an independent body appointed by the Crown to promote the core Civil Service Values of integrity, honesty, objectivity and impartiality through the Civil Service Code, can receive public sector disclosures as a last resort. ${ }^{68}$ This does not pre-empt whistleblower disclosure under the Employment Rights Act 1996 (UK).

There are at least two US government agencies which can protect a whistleblower from retaliation. First is the Office of the Special Counsel ('OSC'), an independent US federal investigative and prosecutorial agency, administers the Whistleblower Protection Act. The OSC was set up to protect federal employee whistleblowers who disclose gross mismanagement, waste of funds, fraud, abuse of authority, breach of the law and a specific danger to public health and safety. It receives, investigates and prosecutes complaints from whistleblowers who claim they have suffered reprisals due to their disclosure of information about misconduct, and provides protection from reprisal. Secondly, there is the Merit Systems Protection Board ('MSPB'), an independent quasi-

65 Public Servants Disclosure Protection Act SC, 2005, c 46.

66 Public Servants Disclosure Protection Act SC, 2005, c 46, s 36.

67 Public Servants Disclosure Protection Act SC, 2005, c 46, s 37.

68 See also Civil Services Commisioners (2008) <http://www.civilservicecommissioners.gov.uk> at 18 August 2008 
judicial agency with the power to adjudicate decisions. It was established to protect federal merit systems against partisan political and other prohibited personnel practices and to ensure that there is adequate protection for employees from abuses by agency management. One of the functions of the MSPB is to adjudicate employee complaints filed under the Whistleblower Protection Act 5 USC $\S 1221(\mathrm{e}) .69$

\section{(c) Public Reporting and Coordination}

Public information and coordination is an important part of any whistleblower program. There must be clear procedures on how a public body is to determine that a disclosure is a public interest disclosure, when the whistleblower must be notified, and whether and when the disclosure will go further such as to the Ombudsman. ${ }^{70}$

Whistleblowers must be aware of the procedures, and whistleblower awareness can be - and must be - enhanced by public education, training and support. For example, some jurisdictions provide that the Ombudsman must prepare and publish guidelines under the Act or at the least an annual report. Ideally, agencies should report to parliament. ${ }^{71}$ Under the Canadian Act, for example, the Commissioner, in addition to submitting an annual report to Parliament, may make special reports in respect of urgent or important matters that the Commissioner believes should not be deferred until the annual report is made. ${ }^{72}$ The South African Act requires the Minister to issue guidelines to explain the Act, and government departments must make the guidelines known or give copies to every employee. ${ }^{73}$

\section{(d) Whistleblower Disclosure to Journalists, Members of Parliament, Private Sector Organisations}

Since whistleblower legislation is important to maintaining accountability in the public sector, whistleblowing to non-government organisations such as the media and parliament should be encouraged, respected and protected in a democratic society to bring evidence of wrongdoing to the attention of the public:

69 US Merit Systems Protection Board < http://www.mspb.gov> at 18 August 2008. The MSPB and the OSC were set up under the Civil Service Reform Act USC (1978). Employees are not protected by First Amendment: Garcetti v Ceballos 547 US 410 (2006), discussed in Dylan Blaylock, Supreme Court Rules Against Government Whistleblowers (2006) Government Accountability Project

$<$ http://www.whistleblower.org/content/press_detail.cfm?press_id=482> at 18 August 2008.

70 See, eg, Public Interest Disclosures Act 2002 (Tas) s 34(1); Whistleblowers Protection Act 2001 (Vic) ss 28-31; Public Interest Disclosure Act 2003 (WA) s 23(1)(f).

71 See, eg, Public Interest Disclosure Act 1994 (ACT) s 11; Public Service Act, RSO 1990, c P.47, s 28.41; Whistleblowers Protection Act 1994 (Qld) s 30; Whistleblowers Protection Act 2001 (Vic) s 103A.

72 Public Servants Disclosure Protection Act SC, 2005, c 46, s 38.

73 See, eg, Protected Disclosures Act 2000 (NZ) s 10(4); David Lewis and Tina Uys, 'Protecting Whistleblowers at Work: A Comparison of the Impact of British and South African Legislation' (2007) 49(3) Managerial Law 76. As at 2008, no guidelines have been issued in South Africa. 
on its own, the public sector cannot deliver results. Civil-society groups and other non-state actors, such as the private sector and the media, are critical in holding the public sector accountable and in advocating needs and priorities. ${ }^{74}$

This may lead to official action on disclosures.

\section{(e) Whistleblower Disclosure to Journalists}

There is a long tradition of whistleblower disclosure to the media - a disclosure which is especially important if there is no other authority to approach and the whistleblower has no other alternative than to go public. Indeed, in some cases sunlight is said to be the best disinfectant. ${ }^{75}$ In the words of one of Australia's senior journalists, 'leaks, and whistleblowers, are essential to a proper democratic system'76 Leaks in many jurisdictions are, however, illegal, so whistleblowing protection for leakers would be a major challenge to existing laws and practices. Disclosure to the media and parliament should be one of the foundations of a democratic society, and should be encouraged and protected ${ }^{77}$ It has been said that disclosure to the media is so important that it is the only true example of 'whistleblowing' behaviour.

Employers may be slow to respond to whistleblower disclosures - whether intentionally or unintentionally - and nothing will lead to a response as effectively as the whistleblower going public through making a disclosure to the media. For example, the disclosure of the 'Pentagon Papers' in 1971 by former US defence department employee Daniel Ellsberg to The New York Times and The Washington Post revealed differences in what the then US Government was stating publicly compared to what it was thinking privately regarding the US war in Vietnam. ${ }^{79}$ The US Government failed in its attempt to stop publication, ${ }^{80}$ and

74 Effective and Accountable Public-sector Management-Strategic Priorities for Danish Support to Good Government (2007) Ministry of Foreign Affairs of Denmark Aid Management Guidelines 3 $<\mathrm{http}: / /$ amg.um.dk/en/menu/policiesandstrategies/goodgovernance/publicsectormanagement/publicsector management.htm $>$ at 18 August 2008.

75 Louis Brandeis, Other People's Money, and How the Bankers Use It (first published 1914, 1986 ed), 92.

76 Laurie Oakes, 'Pillars of Democracy Depend on Leaks', The Bulletin, 24 August 2005; Kathryn Flynn, 'Covert Disclosures: Unauthorised Leaking, Public Officials and the Public Sphere' (2006) 7(2) Journalism Studies 256.

77 Elletta Callahan, Terry Dworkin and David Lewis, 'Whistleblowing: Australian, UK, and US Approaches to Disclosure in the Public Interest' (2004) 44(3) Virginia Journal of International Law 879, 905.

78 See, eg, Damian Grace and Stephen Cohen, Business Ethics: Australian Problems and Cases (1998) 150. Disclosure to the media may be from the whistleblower's own sources, or it may overlap with freedom of information. For example, Sweden states that 'The principle of public access to information means that the public and the mass media - newspapers, radio and television - are entitled to receive information about state and municipal activities': Ministry of Justice, Stockholm, Sweden, Public Access to Information and Secrecy with Swedish Authorities, Information Concerning Secrecy Legislation etc (2004) Regeringskansliet Government Offices of Sweden 7

$<$ http://www.sweden.gov.se/content/1/c6/03/68/28/b8e73d81.pdf $>$ at 18 August 2008; Sweden - The Freedom of the Press Act (1994) ICL Sweden <http://www.servat.unibe.ch/icl/sw03000_html $>$ at 18 August 2008.

79 History of the US Decision-making Process on the Vietnam Policy was a classified document of 2.5 million words commissioned by then Secretary of Defense Robert McNamara in 1967.

80 New York Times v United States, 403 US 713, 822 (1971); Daniel Ellsberg, Secrets: a Memoir of Vietnam and the Pentagon Papers (2002). 
this disclosure helped to hasten the end of the war and the withdrawal of US troops. The rights of journalists have been further advanced by decisions of the European Court of Human Rights upholding their freedom of expression. In Voskuil $v$ The Netherlands, ${ }^{81}$ the Court held that the imprisonment of a journalist for refusing to disclose the identity of a confidential source was a breach of the right to freedom of expression under Article 10 of the European Convention on Human Rights:

Protection of journalistic sources is one of the basic conditions for press freedom, as is recognised and reflected in various international instruments including the Committee of Ministers Recommendation ... Without such protection, sources may be deterred from assisting the press in informing the public on matters of public interest. As a result the vital public-watchdog role of the press may be undermined and the ability of the press to provide accurate and reliable information may be adversely affected. Having regard to the importance of the protection of journalistic sources for press freedom in a democratic society and the potentially chilling effect an order of source disclosure has on the exercise of that freedom, such a measure cannot be compatible with Article 10 of the Convention unless it is justified by an overriding requirement in the public interest. ${ }^{82}$

There was no such overriding public interest requirement in this case to balance with the interests of democracy. In a second recent case, the Court upheld the right of the Head of the Press Department of the Moldovan Prosecutor General's Office to disclose attempted intimidation of the Office to the media as a feature of a democratic society. ${ }^{83}$ There was evidence that the applicant was acting in good faith. There was no evidence that he was seeking any personal advantage, that he was motivated by any personal grievance, or that there was any ulterior motive for his actions. The Court was of the view that the public interest was served with the disclosure of illegal conduct in the form of undue pressure, that this warranted protection, and that this outweighed any interest in maintaining public confidence in the Prosecutor General's Office. Discussion of topics of public concern was confirmed as essential in a democracy, and it was held that members of the public should not be discouraged from speaking up.

These decisions sit alongside the legislative protections for whistleblowers to disclose to the media in many jurisdictions such as the Commonwealth, New South Wales and in the United Kingdom. Such protections are hedged with prerequisites and preconditions which suggest that they are more concerned with 
proper process than with disclosure in the public interest. ${ }^{84}$ Protection for disclosure to the media was recommended by the Bundaberg Hospital Commission of Inquiry in Queensland. ${ }^{85}$ It has been suggested that it is not in the interests of government to have media exposure of corruption unless leaks can be orchestrated to be used to government advantage. In the words of De Maria, 'the State has no "interest" in protecting the media whistleblower'. ${ }^{86}$

Disclosure by journalists came into focus in Australia after the Kessing case. A former Australian Customs Service Officer, Allan Kessing, should have been rewarded - not prosecuted - when two documents were disclosed relating to drug offences and airport security breaches which had not been acted upon. These documents were ultimately published by The Australian newspaper. Kessing denied leaking the documents. He was prosecuted and convicted under the Crimes Act 1914 (Cth) ${ }^{87}$ Following Kessing's disclosures, the Commonwealth Government appointed a committee which recommended increases in airport security. Another hero public servant was Desmond Kelly, who was also charged under the Crimes Act 1914 (Cth $)^{88}$ with releasing information to two journalists from Melbourne's Herald Sun about a report that the Federal Government was planning to deny war veterans an increase in benefits. The journalists refused to reveal the source of the leaked document, were charged with contempt of court, and were convicted and fined $\$ 7000$ each. ${ }^{89}$ Despite the prosecution, the Commonwealth agreed that it was undesirable for journalists to be penalised for honouring their professional ethics, and even intervened in the Victorian case to argue that the journalists should not be charged and, having been convicted, that they should be pardoned. The perceived inconsistency in the Commonwealth's

84 Journalist protection was enacted in the Evidence Amendment (Journalists' Privilege) Act 2007 (Cth), discussed in, eg, Evidence Amendment (Journalists' Privilege) Bill 2007 (Cth), Department of Parliament, Parliament of Australia, 8 June 2007, which now protects confidential communications between journalists and their sources. It was also recommended in the Private Members' Bill Public Interest Disclosures Bill 2007 (Cth) cl 9(2), which was introduced in June 2007. Under the Protected Disclosures Act 1994 (NSW), ss 8(1)(d), 19(1)-(3), a whistleblower may only disclose to the media, with any chance of being protected, if relevant authorities have first had six months to consider the matter, and if able to prove that the suspicion of wrongdoing is 'substantially true'. Under the Employment Rights Act 1996 (UK) c 18, Part IVA (Protected Disclosures) ss 43G, 43H, the disclosure must meet three tests relating to the evidence and motive of the whistleblower, a number of other preconditions, and the requirement that the disclosure must be reasonable in all the circumstances.

85 The Hon Geoffrey Davies AO, Queensland Public Hospitals Commission of Inquiry Report (2005) Queensland Government 472 [6.512] <http://www.qphci.qld.gov.au/final_report/Final_Report.pdf > at 18 August 2008

86 William De Maria, 'Common law - Common Mistakes?: Protecting Whistleblowers in Australia, New Zealand, South Africa and the United Kingdom' (2007) 19(7) International Journal of Public Sector Management 643, 649.

87 Crimes Act 1914 (Cth) s 70(2): 'Disclosure of information by Commonwealth officers'. Kessing was sentenced to nine months' jail for breach of his duty of confidentiality, suspended: $R v$ Kessing [2007] NSWDC 138.

88 Crimes Act 1914 (Cth) s 70(1): 'Disclosure of information by Commonwealth officers'.

$89 R$ v McManus and Harvey [2007] VCC 619. Although Kelly was found guilty of releasing confidential information, the conviction was overturned by the Victorian Supreme Court on the basis that there was insufficient evidence to support the conviction: $R$ v Kelly [2006] VSCA 221, [62]. 
position caused the sentencing judge, Rozenes CJ of the Victorian County Court, to reportedly describe the Commonwealth as suffering from a 'serious case of schizophrenia'. ${ }^{90}$ The different approaches to a public interest defence for whistleblowers regarding media disclosure is a serious anomaly in relation to what should be regarded as a necessary and valued means of disclosure.

\section{(f) Whistleblower Disclosure to Members of Parliament}

Disclosure, including whistleblower disclosure, underlies a representative democracy, and disclosure to elected representatives should be protected under parliamentary privilege. Disclosure to a member of parliament with legal protection should be included in any model of whistleblower legislation. Many jurisdictions do provide for protected disclosure to a member of parliament. ${ }^{91}$ The democratic process should promote disclosure and debate under parliamentary privilege. ${ }^{92}$

\section{(g) Whistleblower Disclosure to Private Sector Bodies}

Private sector agencies, watchdogs, centres and campaigning organisations like the National Whistleblower Center ('NWC') in the US are important places for disclosure. The NWC has won reinstatement for whistleblowers, collected damages, forced government agencies to release information documenting government misconduct and exposed various classes of misconduct. ${ }^{93}$

In the UK, there is an organisation known as 'Public Concern At Work', and in the US, the US Government Accountability Project ('GAP'). ${ }^{94}$ The National Security Whistleblowers Coalition is a non-profit public interest group set up in 1977 to promote government and corporate accountability by advancing occupational free speech, defending whistleblowers and empowering citizen activists. ${ }^{95}$ Such agencies are usually independent and non-profit and act in the public interest to protect whistleblowers. For example, GAP has been a leader of public campaigns for many United States national whistleblower laws. Not to be overlooked is the important role played by legal aid to open the doors of the courts. Whistleblower models are mixed on the question of the availability of legal aid.

90 Samantha Maiden, 'Ruddock says Contempt Pardon "Worth Considering", The Australian, 27 June 2007. See also A J Brown, 'Privacy and the Public Interest Disclosure: When is it Reasonable to Protect “Whistleblowing” to the Media?' (2007) 4(2) Privacy Law Bulletin 19; Moss Report, above n 18, ch 5.

91 See, eg, Public Interest Disclosures Bill 2007 (Cth), cl 9(1); Protected Disclosures Act 1994 (NSW) s 8(1)(d); Protected Disclosures Act 2000 (NZ) s 10(1); Protected Disclosures Act 2000 (South Africa) s 7; Employment Rights Act 1996 (UK) c 18, s 43E(b).

92 Under s 8(1)(d) of the Protected Disclosures Act 1994 (NSW), a whistleblower is to make a protected disclosure to a member of Parliament.

93 National Whistleblower Centre, Our Work<http://www.whistleblowers.org/html/our_work.html $>$ at 18 August 2008.

94 GAP is the US's leading whistleblower organisation; Government Accountability Project $<$ http://www.whistleblower.org/template/index.cfm> at 18 August 2008.

95 National Security Whistleblower's Coalition <www.nswbc.org $>$ at 18 August 2008. 


\section{WHAT CAN BE DISCLOSED - DISCLOSABLE WRONGDOING}

\section{A Consistent Legal Thresholds 1 - Types of Conduct}

An effective whistleblower protection scheme should serve the public interest. The definition of 'public interest' varies, however, across different jurisdictions due to different political and legal cultures. There are many differences in the type of wrongdoing which will qualify as a protected disclosure and the exemptions provided. No doubt the different jurisdictions are all aware of the perceived problem of whistleblower legislation opening the disclosure floodgates.

There are many different protected disclosures, and there are inconsistent and irrational differences in what can be disclosed. For example, the Canadian Act, an Act which limits 'wrongdoing' to the public sector, promotes disclosure of a breach of a federal or provincial Act or regulation; the misuse of public funds or assets; gross mismanagement in the Canadian federal public sector; an act or omission which creates a substantial and specific danger to the life, health or safety of persons or to the environment; taking a reprisal against a public servant, and knowingly directing or counselling a person to do any of these things. ${ }^{96}$ The Canadian Act does not include disclosure of breach of legal obligations at common law or in equity such as breach of a fiduciary obligation. Such breaches may be disclosed under the South African Act as disclosure of breach of 'any legal obligation', ${ }^{97}$ or under the Whistleblower Protection Act in the US, which includes protection of disclosures of corruption and misuse of public funds and breaches of the law that federal employees may encounter in the workplace, including abuse of authority; mismanagement; endangerment of public health or safety and squandering.

Best Practice is for protected disclosures to promote and to protect free expression with 'No Loopholes' ${ }^{98}$ Protected disclosures should cover any wrongdoing, with no technicalities (loopholes) of form over substance. Wrongdoing would include disclosure of abuse of authority, danger to public health or safety, and gross waste, illegality and mismanagement. ${ }^{99}$ Of course this would be problematic in the case of disclosure of information prohibited by legislation or in breach of confidence. A whistleblower should be protected for refusing to obey an order on the grounds that it is illegal. ${ }^{100}$ Protection of acts in good faith stops faits accomplis and may

96 Public Servants Disclosure Protection Act SC, 2005, c 46, ss 2, 8. The legislation establishes a list of 'wrongdoings' that public servants may disclose, including contraventions of federal or provincial statutes, misuse of public funds, 'gross mismanagement' in the public sector, any act that creates a substantial danger to the life, health or safety of persons or to the environment, and reprisals against a public servant for making a disclosure under the Act.

97 Protected Disclosures Act 2000 (South Africa) s 1(i)(a).

98 Devine, above n 40, [1] citing, eg, UN Policy above n 40, s 4; OAS Model Law ss 2(d)-(f); Whistleblower Act 2005 (Ghana) s 4.

99 Ibid, [2] citing, eg, UN Policy, above n 40, s 2.1(a); OAS Model Law, Article 2(c); SOX, (2002) 18 USC 1514(a); Whistleblower Act 2005 (Ghana), s 1.

100 Ibid, [3] citing, eg, OAS Model Law, arts 2(c), (5). 
prevent the need for whistleblowing, but a whistleblower who refuses to obey an order on the grounds that it is illegal may run the risk of later discipline if the order is later found not to have required illegal conduct. Therefore whether a person can disclose the following under whistleblower laws will have different answers in different jurisdictions.

\section{Disclosure of Illegal and Corrupt Conduct}

The starting point for whistleblower disclosure is disclosure of illegal and corrupt conduct. Best practice protects disclosure of a 'criminal offence'. ${ }^{101}$ In addition, many jurisdictions protect public servant disclosure of public sector wrongdoing involving a breach of any federal or provincial legislation. ${ }^{102}$ Saskatchewan's Labour Standards Act protects disclosure of 'any activity that is or is likely to result in an offence pursuant to an Act or an Act of the Parliament of Canada'. ${ }^{103}$

Best practice authorises disclosure of corrupt conduct, but what is to be included? A good list of what is considered to be corrupt conduct is set out in the Independent Commission Against Corruption Act 1988 (NSW), which includes any conduct of any person (whether or not a public official) that affects 'the honest or impartial exercise of official functions by any public official ... or any public authority'. The list indicates the matters that a whistleblower should be encouraged to report - official misconduct (including breach of trust, fraud in office, nonfeasance, misfeasance, malfeasance, oppression, extortion or imposition); bribery; blackmail; obtaining or offering secret commissions; fraud; theft; perverting the course of justice; embezzlement; election bribery; election funding offences; election fraud; treating; tax evasion; revenue evasion; currency violations; illegal drug dealings; illegal gambling; obtaining financial benefit by vice engaged in by others; bankruptcy and company violations; harbouring criminals; forgery; treason or other offences against the Sovereign; homicide or violence; matters of the same or a similar nature to any listed above or any conspiracy or attempt in relation to any of the above. ${ }^{104}$ Equally, the Independent Commission Against Corruption Act 1988 (NSW) excludes conduct which could be a criminal, disciplinary or related offence. ${ }^{105}$

\section{Disclosure of Public Wastage}

The potential for non-disclosure of wastage of public funds and resources by a public authority or by any of its officers highlights the importance of disclosure in annual reporting. This provides information for the media and the political

101 See, eg, Protected Disclosures Act 2000 (South Africa) s 19(i)(a): query that a breach of the law is not an offence until there has been a judgment by a court; Employment Rights Act 1996 (UK) s 43B (a) that a criminal offence has been committed, is being committed or is likely to be committed is a protected disclosure.

102 Public Servants Disclosure Protection Act, SC 2005, c 46, s 8(a).

103 The Labour Standards Amendment Act, SS 2005, c 16, ss 8, 74(1)(a).

104 Independent Commission Against Corruption Act 1988 (NSW) s 8(2).

105 Independent Commission Against Corruption Act 1988 (NSW) ss 8(1)(a), 9. 
process. Hence best practice whistleblower legislation, such as in Canada, expressly protects disclosure of misuse of public funds or a public asset. ${ }^{106}$ If there is no such provision, there may be a fall-back protection for whistleblowers of public wastage as a failure to comply with a legal obligation. ${ }^{107}$

\section{Disclosure of 'Maladministration'}

The internal witness - the whistleblower - has access to information about misconduct in the organisation. Best practice promotes whistleblower disclosure of maladministration, such as for example Canada's protection of disclosure of 'gross mismanagement in the public sector'. ${ }^{108}$

The targets of the European Ombudsman give good examples of what is maladministration, starting with tenders and contracts, stated to include procurement contracts and contracts where the Commission provides grants or subsidies. ${ }^{109}$ The European Ombudsman also targets the Commission's role as 'Guardian of the Treaty', which means enforcing European law against a Member State that fails to comply with the law. Further, complaints about personnel matters, including recruitment and complaints from existing staff are also targeted, as well as the lack of openness (especially refusal of access to documents) and complaints concerning maladministration (including such matters as abuse of power, administrative irregularities, discrimination, failure to reply, refusal of information, unfairness and unnecessary delay).

\section{Disclosure of Danger to Public Health, Safety and the Environment}

An important public role of the whistleblower is disclosure of danger to public health, safety and the environment. For example, an officer of a planning department who knows that a bridge is not safe or that a building approval has been obtained corruptly is the kind of hero that whistleblower law should be protecting. Danger to public health and safety ${ }^{110}$ and danger to the environment ${ }^{111}$ are included in the legislation or proposed legislation in many jurisdictions.

106 See, eg, Protected Disclosures Act 1994 (NSW) s 12; Whistleblowers Protection Act 1994 (Qld) s 17; Public Servants Disclosure Protection Act SC, 2005, c 46, s 8(b).

107 See, eg, Protected Disclosures Act 2000 (South Africa) s 1(i)(b).

108 Public Servants Disclosure Protection Act SC, 2005, c 46, s 8(c).

109 P Nikiforos Diamandouros, 'The Role of the European Ombudsman' (Speech delivered at the British and Irish Ombudsman Association Conference, Warwick University, 8 April 2005 ).

110 See, eg, Public Interest Disclosure Act 1994 (ACT) class (d) of s 3 'public interest disclosure'; Public Servants Disclosure Protection Act, SC 2005, c 46, s 8(d); Public Interest Disclosures Bill 2007 (Cth) cl 5; Employment Rights Act 1996 (UK) c 18, s 43B(1)(d).

111 See, eg, Public Interest Disclosures Bill 2007 (Cth) cl (i), (iii); Employment Rights Act 1996 (UK) c 18, s 43B(1)(e). 


\section{CIVIL AND CRIMINAL INDEMNITY}

Best practice supports whistleblower disclosure of wrongdoing, and provides that a person is not liable, civilly, criminally or under an administrative process for making a public interest disclosure. ${ }^{112}$

Disclosure may make the whistleblower appear to some to be a traitor because of what would appear to involve a breach of confidentiality. Only some legislation overrides the duty of confidentiality, secrecy or other restrictions on disclosure by providing for whistleblower protection. ${ }^{113}$

One solution, although doubted by some, would be a policy to promote whistleblower disclosure by rewarding whistleblowers. There is disagreement on this, with some arguing for rewards to stimulate disclosures and others arguing that whistleblowers should be motivated by altruism.

Rewards could be paid if and when the content of a disclosure is proven and followed up, and could take the form of financial incentives to offset the usual financial risks and burden of making disclosure. Examples include bounties, a share of the savings or a share in the restitution. Such rewards could be similar to the False Claims Act 31 USC $\S \S 3729-3733$ in the US which contains a qui tam provision allowing private citizens to take legal action and obtain money in certain situations. ${ }^{114}$ We believe that a real whistleblower policy would offer the option of reinstatement or re-engagement to any whistleblower who has lost their job as a result of making a disclosure. ${ }^{115}$

\section{A Relief from Legal Liability}

The risk that somebody may be defamed by a whistleblower's disclosure is a disincentive for the whistleblower. Existing whistleblower legislation approaches this differently, with some providing absolute privilege against defamation ${ }^{116}$ some providing qualified privilege against defamation, ${ }^{117}$ and others providing protection from defamation through the general immunity provisions. ${ }^{118}$ Frequently legislation provides protection from liability for a person making statutory reports. ${ }^{119}$ For example, if the whistleblower's reasonable belief in the content of the disclosure proves to be incorrect, the whistleblower may be able to

112 See, eg, Public Interest Disclosures Bill 2007 (Cth) cl 17; Protected Disclosures Act 1994 (NSW) s 21; Whistleblowers Protection Act 1994 (Q1d) s 39; Whistleblowers Protection Act 1993 (SA) s 5.

113 See, eg, Public Interest Disclosures Bill 2007 (Cth) cl 17(2)(b), (c); Protected Disclosures Act 1994 (NSW) ss 21(2)-(3).

114 Earle and Madek, above n 38, 53

115 Lewis and Homewood, above $n 39$.

116 See, eg, Public Interest Disclosures Bill 2007 (Cth) cl 17(2)(a); Whistleblowers Protection Act 2001 (Vic) s 16.

117 See, eg, Public Interest Disclosure Act 1994 (ACT) s 35(2).

118 See, eg, Protected Disclosures Act 2000 (NZ) s 18; Whistleblowers Protection Act 1993 (SA) s 5; Public Interest Disclosures Act 2002 (Tas) ss 16-17; Public Interest Disclosure Act 2003 (WA) s 13.

119 See, eg, Protections for Persons Reporting Child Abuse Act 1998 (Ireland) ss 3, 4. See also The Commissioner for Children and Young People (Northern Ireland) Order 2003 (NI) arts 9-10; The Protection of Children and Vulnerable Adults (Northern Ireland) Order 2003 (NI) art 19. 
be sued for defamation. Best practice should protect whistleblowers from civil and criminal liability if they make a protected disclosure, and they should be afforded absolute privilege..$^{120}$

\section{B Relocation}

Whistleblowing might come at a high personal and professional cost, with reprisal, retaliation or the risk thereof so serious that the whistleblower may only feel safe by relocating and starting a new life. Whistleblower best practice should include entitlement to transfer or to relocate. ${ }^{121}$

\section{WORKPLACE RELATIONS PROTECTIONS FOR THE WHISTLEBLOWER}

Best practice recognises that whistleblowers add value to the flow of information about an organisation, employer or company. Outsiders who are aware of a strong whistleblower policy would see increased release of information, giving increased credibility. In the case of a company, this may lead to an increase in investor confidence. Best practice promotes whistleblower disclosure by prohibiting employers from restraining free speech by imposing confidentiality on a whistleblower (in the US, 'gag orders') with policies, rules or by nondisclosure agreements designed to limit free speech. ${ }^{122}$

The effectiveness of whistleblower regulation will depend on its ability to protect whistleblowers from reprisal. This can take the form of prohibiting reprisals in whistleblower legislation, through sanctions or remedial powers by agencies. ${ }^{123}$

There is evidence that some or too many whistleblowers suffer significantly and permanently for their disclosure, and it seems that unfortunately, in De Maria's words, 'the non-suffering' whistleblower is 'a contradiction in terms'. ${ }^{124}$ Best practice must promote openness. It must encourage whistleblower disclosure and provide remedies for reprisals against the whistleblower speaking out, such as by imposing criminal offences, and by providing for civil remedies and immunities. It must provide whistleblower protection against reprisals, harassment and dismissal. ${ }^{125}$

120 Lewis and Homewood, above $\mathrm{n} 39,10^{\text {th }}$ conclusion and recommendation.

121 See, eg, Public Interest Disclosure Act 1994 (ACT) ss 27, 28; Whistleblowers Protection Act 1994 (Qld) s 46; Protected Disclosures Act 2000 (South Africa) s 4(2)(3); Lewis and Homewood, above n 39, $11^{\text {th }}$ conclusion and recommendation.

122 Devine, above n 40, [8], citing, eg, OAS Model Law, art 6; Protected Disclosures Act 2000 (South Africa) ss 2(3)(a), (b).

123 See, eg, in Canada, the Public Service Staff Relations Board or to the Canada Industrial Relations Board; in Israel, the Ombudsman can issue disciplinary or corrective measures under the SCL; in Korea, there are remedies and sanctions dealing with reprisal in the Korean Independent Commission Against Corruptions policies; in the UK, Civil Service Code 1999 s 2; in the US, OSC and MSPB as set out in the Whistleblower Protection Act.

124 De Maria, Deadly Disclosures (1999), above n 2.

125 The Whistleblower Protection Act 2004 (Japan) art 3 provides for 'nullity of dismissal'. 
Examples of reprisals given in, for example, the Canadian Act, ${ }^{126}$ include a disciplinary measure, demotion, termination of employment, any measure that adversely affects the employment or working conditions of the public servant, and making a threat to do any of these. Best practice must also stop reprisal against a third person for cooperating with a whistleblower investigation, such as providing evidence or for 'assisting' whistleblowers - meaning guilt by association. Otherwise, reprisals will continue to have a 'chilling effect that locks in secrecy by keeping people silent and isolating those who do speak out'. ${ }^{127}$ Examples of harassment can include actual or threatened discrimination, or recommending discrimination by others such as by subordinates, including termination, refusal to promote or stopping access to advancement such as access to training. ${ }^{28}$

The legislation generally provides an internal approach. It protects the whistleblower if disclosure is made according to the procedures set out, including protection from reprisal, ${ }^{129}$ but since this protection is in the hands of the relevant government department, it is questionable whether this will be objective. Many reprisals such as ostracism, rumours or minor changes in work assignments may be difficult to prove and may fall below the threshold of proof for successful legal action. Many whistleblowers believe employers harass them in subtle ways to avoid providing evidence of reprisal. This danger has been recognised in Canada:

Ultimately, in this situation, an individual must make their disclosure to their own employer or government department where the wrongdoing likely occurred, and then trust those authorities to be noble enough to protect them from reprisal for making that very disclosure. While some authorities may uphold that responsibility, the reality is that some will not, and that the perception of protection is weak in the eyes of a potential person making the disclosure. ${ }^{130}$

\section{A Employer's Duty of Care to Employee}

Private action by the whistleblower for harassment may become an important motivation for effective whistleblower protection. Rather than relying on whistleblowing statutes, the common law courts may recognise that an employer may be vicariously liable for breach of its duty of care to an employee if there is harassment or reprisal by another employee. For example, ${ }^{131}$ an animal technician reported what she suspected were a staff member's failures to comply with university regulations regarding animal experimentation, which she believed were a substantial health risk. She was then allegedly subjected to reprisals from

126 Public Servants Disclosure Protection Act SC, 2005, c 46, s 2.

127 See, eg, Devine, above n 40, [4] citing, eg, OAS Model Law, arts 2(g), 5.

128 Ibid, [7] citing, eg, OAS Model Law, art 2(g); Sarbanes-Oxley Reform Act (US Publicly Traded Corporations), 18 USC 1514(a) (2002)).

129 See, eg, the Public Service Act 1999 (Cth) and the Australian Government, Australian Public Service Code of Conduct $<$ http://www.apsc.gov.au/conduct/> at 18 August 2008.

130 Government of Canada Public Service Integrity Office, above n 54.

131 Reeves-Board v Queensland University of Technology [2001] QSC 314; cf Howard v State of Queensland [2000] QCA 223 (allegations of vicarious liability could not be sustained and an appeal was dismissed). 
several senior staff members, and was finally sidelined into a lesser role. The employer University failed to have her claim under section 43(2) of the Whistleblowers Protection Act 1994 struck out.

This was developed in Wheadon $v$ State of NSW, ${ }^{132}$ where a policeman, who had reported suspected corrupt conduct to police internal affairs, was subject to harassment and victimisation, and denied welfare assistance. He claimed damages for serious stress and psychiatric illness caused by the employer's failure (1) to provide him with adequate protection from harassment; (2) to properly investigate the allegation; (3) to properly investigate the allegations against him; (4) to give him support and guidance; (5) to prevent his colleagues from persecuting him; and (6) to assure him that he had done the right thing by reporting corruption. This case is important because it shows the seriousness with which the acitons were taken, with damages of over $\$ 650,000$ awarded, and damages and costs of all parties exceeding $\$ 1$ million.

\section{B Reprisal and Protection Against Reprisal}

A major disincentive to blow the whistle is the possibility or probability of reprisal or retaliation. The whistleblower may be seen as disloyal and a traitor to the organisation and its culture. Whistleblower legislation seeks to protect a whistleblower worker from detriment 'on the ground that the worker has made a protected disclosure'.133 The Employment Rights Act 1996 (UK) protects the whistleblower worker from dismissal ${ }^{134}$ and from being selected for redundancy, ${ }^{135}$ with the right to apply for compensation at an employment tribunal. $S O X$, inter alia, aims to promote employee disclosure in public companies, and as a result prohibits retaliation against a whistleblower who provides truthful information to a law enforcement officer about illegal activity. Employees who are successful in a claim of retaliation may receive a remedy that includes reinstatement, back pay, attorney fees, costs and 'special damages'. There are difficulties for former employees in pursuing a case for reinstatement while unemployed - perhaps for years - if there are appeals. An organisation may refuse to take back a worker even in the face of court judgments. In the words of the UN Policy:

132 (Unreported, District Court, Cooper J, 2 February 2001). See also David Landa, 'Whistleblowing: Betrayal or Public Duty' <http://www.transparency.org.au/documents/dland6aug.pdf $>$ at 18 August 2008.

133 Protected Disclosures Act 2000 (South Africa) s 3. This Act provides that dismissal of a whistleblower is deemed to be automatically unfair under the Labour Relations Act 1995 (South Africa); Employment Rights Act 1996 (UK) c 18, s 47B(1), discussed, eg, Lewis and Uys, above n 73.

134 Employment Rights Act 1996 (UK) c 18, s 103A.

135 Employment Rights Act 1996 (UK) c 18, s 105(6A). 
1.3 Retaliation against individuals who have reported misconduct or who have cooperated with audits or investigations violates the fundamental obligation of all staff members to uphold the highest standards of efficiency, competence and integrity and to discharge their functions and regulate their conduct with the best interests of the Organisation in view. ${ }^{136}$

This is similar to the many statutes which give immunity to witnesses or persons who are just doing their job. ${ }^{137}$

Some jurisdictions, such as Canada, provide that the whistleblower can bring complaint of reprisal to the Public Sector Integrity Commissioner. Bringing a complaint freezes any disciplinary action while the complaint is afoot. An adverse outcome regarding reprisal may be appealed to the Public Servants' Disclosure Protection Tribunal, which can make orders such as a return to work, reimbursement of expenses, or payment of compensation.

Whistleblower legislation usually authorises criminal action in the courts in relation to unlawful reprisals, with a penalty upon conviction. ${ }^{138}$ The legislation usually also provides for action for damages against a person who takes detrimental action as reprisal. Civil damages may be recovered as for a tort ${ }^{139}$ to place the whistleblower in the position he or she would have been in but for the reprisal, providing compensation rather than punishment or retribution. Some jurisdictions provide for an award of exemplary damages. ${ }^{140}$ In addition, whistleblower legislation provides for injunctions to restrain detrimental action for making a protected disclosure. ${ }^{141}$ Our researchers have found few reported cases on reprisal, confirmed by, for example, Canada, which has reported that ' $[\mathrm{t}]$ he results thus far are uncertain because there have been very few reprisal cases in the courts'. 142

\section{CONCLUSIONS}

This article is based on the assumption that effective whistleblower laws are needed to further the operation of a democratic society. It is true that since the 1990s many public law jurisdictions have passed, or are committed to passing, legislation to protect public interest whistleblowers. The existence or the effectiveness of these whistleblower laws correlates with the ranking of countries

136 UN Policy, above n 40.

137 See, eg, Ombudsperson for Children Act 2003 (Mauritius) ss 8, 9; Protection of Persons Acting Under Statute Act, RSNB 1973, c P-20.

138 See, eg, Public Interest Disclosure Act 1994 (ACT) s 25; Protected Disclosures Act 1994 (NSW) s 20, described as a summary offence: s 29; Whistleblowers Protection Act 1994 (Qld) s 42, with a maximum of two years prison; Protected Disclosures Act 2000 (South Africa) s 4.

139 See, eg, Whistleblowers Protection Act 1994 (Qld) s 43; Public Interest Disclosures Act 2002 (Tas) s 20(2); Whistleblowers Protection Act 2001 (Vic) s 19; Public Interest Disclosure Act 2003 (WA) s 15(1).

140 See, eg, Public Interest Disclosures Act 2002 (Tas) s 20(3); Whistleblowers Protection Act 2001 (Vic) s 19(3). The Whistleblowers Protection Act 1993 (SA) s 9(2)(b) provides a remedy under the Equal Opportunity Act 1984 (SA) for victimisation.

141 See, eg, Public Interest Disclosures Act 2002 (Tas) ss 21, 22; Whistleblowers Protection Act 2001 (Vic) ss 20,21 .

142 Government of Canada Public Service Integrity Office, above n 54, 10. 
by Transparency International. Correlation does not prove causation, and it could be that whistleblower laws are as much a consequence of open and honest practices as a cause. In countries where workers have confidence in high-level honesty, they are more likely to speak out - and be surprised about reprisals. Publicity about such cases may then stimulate governments to pass whistleblower laws.

Effective whistleblower protections must include access to the normal legal process including trial by jury, protection for the whistleblower and protection of lawful disclosure. There must be no retaliation and there must be effective resolution of the wrongdoing disclosed by the whistleblower.

Having good whistleblower laws is undoubtedly important, but so is enforcement. Failures of implementation or enforcement may undermine good laws, and there are many sceptical comments about the various avenues open to whistleblowers, from hotlines to false claims legislation. For example, Devine points out that ' $[\mathrm{b}]$ etween passage of the 1994 amendments and September 2002, whistleblowers lost 74 of 75 decisions on the merits at the Federal Court of Appeals, which has a monopoly on judicial review of administrative decisions'. ${ }^{143}$ Given that the US is in its second or third generation of whistleblower laws, the existence of scepticism about whistleblowing law effectiveness and enforcement, or about poor prospects in pursuing redress, remains an important issue.

We conclude that no single jurisdiction demonstrates a current best practice model for whistleblower laws. We identify a strong case for greater consistency in the key legal thresholds and operational requirements imposed by different national whistleblower protection regimes, including useful potential common tests and processes covering both the public and private sectors. In large part, the prospect for accelerating the transition towards more effective, less 'symbolic' regimes depends on a clearer consensus regarding the public importance of employee disclosures and the organisational advantages of open, proactive approaches to disclosure management.

Each jurisdiction has enacted at least some of the elements of best practice, but all have problems based on their unique political and social environments sometimes unique, sometimes general or common problems. We recommend the need for a second generation of whistleblower laws, drawing on the lessons of the first generation laws discussed in this article. The important whistleblower issues are common whether in Australia or in Zimbabwe, and global public integrity and standards would benefit from a clearer and legislatively supported consensus.

143 Tom Devine, in Calland and Dehn, above n 9, 85; see also, Tom Devine, Courage Without Martyrdon: the Whistleblower's Survival Guide (1997). The Report to Congress for 2006 of the Office of the Special Counsel (US) showed that 478 of 545 disclosures were processed and closed during the year. Only 24 (5 per cent) were determined by the Special Counsel to indicate wrongdoing and were referred to agency heads for investigation and report: Scott Bloch, Fiscal Year 2006 Report (2006) US Office of Special Counsel <http://www.osc.gov/documents/reports/ar-2006.pdf> at 18 August 2008. 
While progress is needed towards more comprehensive standards, the most important requirement of all is care and deliberation over the nature of current legislative strengths and weaknesses. The legislation is of great public importance. By suggesting a new framework for comparison and evaluation of these laws it is hoped that new steps can be taken towards ensuring its effectiveness, first through clearer discussion of its fundamental principles, and then a clearer consensus on what 'best practice' might represent. 